Marijola Božović ${ }^{1}$

Higher Technical Professional School in Zvečan

Snežana Živković

University of Niš, Faculty of occupational safety in Niš
ORIGINAL SCIENTIFIC ARTICLE DOI:10.5937/ekonomika1702055B

Received: March, 21, 2017

Accepted: April, 03, 2017

\title{
MINIMIZING INJURY INCIDENCE RATE FOR MEMBERS OF THE FIRE RESCUE BRIGADES - SYSTEMATIC APPROACH
}

\begin{abstract}
The objective of the research is the identification and determination of requirements of the members of fire rescue brigades during the interventions in the conditions of high risk in order to minimize the possibilities for injuries during the intervention. Results indicate that almost half of respondents need further education for the purpose of identification, assessment and management of the risks that can lead to emergency situations and that education would be helpful in acquiring knowledge and abilities to help jeopardized population. Systematic overview of objectives, necessary measures and research activities is given as a guideline for improvement of domestic national system of emergency situations management.
\end{abstract}

Key words: fire rescuers, integrated safety system, injury incidence, risk assessment

JEL classification: 131, J28

\section{МИНИМИЗИРАЫЕ УЧЕСТАЛОСТИ ПОВРЕДА ПРИПАДНИКА ВАТРОГАСНО-СПАСИЛАЧКИХ БРИГАДА - СИСТЕМСКИ ПРИСТУП}

\begin{abstract}
Апстракт
Циљ истражсивања је идентификација и утврђивање услова за припаднике ватрогасно-спасилачких бригада током интервенција у условима високог ризика у цииьу минимизирања могућности настајања повреда током интервенције. Резултати показују да је скоро половини испитаника потребна додатна едукација у цุиьу идентификачије, процене и управљања ризицима који могу довести до ванредних ситуащија и да би едукащија била од помоћи у стищању знања и способности да се помогне угроженом становништву. Систематски преглед циивева, неопходних мера и истраживачких активности презентован је као смерница за унапређене домаћег националног система управљања ванредним ситуачијама.
\end{abstract}

Кључне речи: ватрогасци-спасиочи, интегрисани систем безбедности, инщидениза повреда, прочена ризика

\footnotetext{
${ }^{1}$ m.bozovic@vts-zvecan.edu.rs

${ }^{2}$ snezana.zivkovic@znrfak.ni.ac.rs
} 


\section{Introduction}

In recent years, topicality, unpredictability and severity of emergencies have encouraged numerous discussions and raised series of questions regarding the issue of occupational (Chen et al., 2015) and environmental safety in emergency management (Qinqin et al., 2014). Given the increasingly complex current challenges, the capacity of problem solving surpasses the abilities of individuals and requires coordinated action of all participant who are responsible for crises management (Boin, 2009; Kazmierczak, 2011). According to Helsloot, it seems to be common scientific knowledge nowadays that command and control in crisis management is an old-fashioned concept but that it is coordination that we should strive for (Helsloot, 2008).

There is an issue of building an adequate system of crisis management at the state and other forms of political-territorial organization level, but also in public enterprises, the profit sector and education, and other areas. It is necessary for this system to be conceptually and software designed and scientifically based and founded. In addition, it has been investigated in what way the education, as the fundamental prevention measure in the complex system of protection and safety of the environment can respond to the current workplace requirements of the members of fire brigades. Of global social interest and significance is that through the process of permanent influence on the individual, his knowledge and skills, habits, attitudes and behaviour is possible to develop the safety awareness, culture of crisis management, that is, prevention or avoidance of the risks in the working and living environment that can lead to crises, emergencies, fatalities and the loss of natural and material assets (Živković, 2011). The occupational and environmental safety is an essential need, value and interest of each individual and humankind as a whole, which is closely related to the conditions of both existence and sustainable future development.

\section{Scientific and social significance of the research}

Region of the Southeast Europe is increasingly threatened by different types of natural disasters, of which some occur suddenly, unexpectedly and are life-threatening. They occur in different forms and sizes like floods, droughts, extremely high temperatures, earthquakes, landslides, storms etc. (Keković \& Kešetović, 2006). Minimizing the impact of disasters requires effective management of the emergency through coordination of resources and actions from the many different responding organizations (Ford \& Schmidt, 2000). Over the years, the European Union (EU) has developed a series of capacities in order to coordinate the respond of the member states to natural disasters and foreign crises (Boin, Ekengren \& Rhinard, 2013). Through the completely new Emergency Response Centre that is engaged in activities to raise the awareness among people on the importance on how every moment is important for saving the human lives, as well as the field training in simulated emergencies, Emergency Response Coordination Centre (ERCC) operates within the European Commission's Humanitarian Aid and Civil Protection department (ECHO) and coordinates the joint assistance in disasters, both in Member States and in all other countries affected by disasters (Hollis, 2012). The EU supports states outside the EU through different civilian and military missions 
(Tercovich, 2014). National governments can not deal with these crises unilaterally, nor can they isolate themselves from these threats. The world, especially Europe, becomes too connected and intertwined to avoid any crisis.

A combination of mentioned factors requires comprehensive strategy for the protection and rescue in emergency situations that includes the systems for prevention, protection and rescuing, mitigation and renovation (Mastrjukov, 2005). Serbia is now in the process of harmonization of overall legislative and institutional framework with numerous international requirements and standards in the field of emergency situations management. For the Republic of Serbia, the year 2009 has marked a new beginning in the development of a national system for emergency management by enacting the Law on emergency situations "Official Gazette of the Republic of Serbia” no. 111/2009, 92/2011, 93/2012). The integrated approach to emergency situations management aims to contribute to the safety of the people; occupational and environmental safety and in this effort Serbia enjoys the support to membership in the Regional Cooperation Council for the South Eastern Europe - DPPI (Disaster Preparedness and Prevention Initiative), the European Council EUROPA and International Strategy for Disaster Reduction UNISDR.

Taking into account the presented facts, it is important to emphasise how important and necessary is to continuously explore in the area of safe working and living environment, bearing in mind that oncoming disasters and risks put modern society and its knowledge aboutthem to the test so it is necessary to permanently and responsibly direct capacities of all relevant factors to the study of these phenomena.

By analyzing the available literature that deals with the research of safe and healthy working conditions for the members of fire rescue brigades, authors have concluded that there was very little progress in research of safe and healthy working conditions for members of fire rescue brigades during their interventions. Namely, very few authors have tried to deal with this issue, which was unfairly neglected, even though it is known that workplace of firemen is a workplace with an increased risk. The profession of firemenrescuers is very demanding both from a psychological and physical aspect, where the risk of exposure to hazards is usually high. During the performance of working activities, the firemen are regularly exposed to very hazardous and traumatic occurrences. The analysis of available literature that deals with this issue led to the conclusion that most of hazardous traumatic occurrences can lead to the situation that involves the loss of life, physical injury, coping with death and injuries of colleagues and people assisted through (Moran \& Britton, 1994; Beaton et al., 1999).

\section{Subject, goal and tasks of the research}

Modern safety challenges, risks and threats have increased the interest for problems of occupational and environmental safety. Members of fire rescue brigades as one of the subjects of an integrated system of safety, protection and rescuing of people, assets and environment in general are the subject of this research in the context of the occupational and environmental safety. The research is directed to:

- Examination, determination and identification of factors that affects the increased number of occupational injuries of the members of fire rescue 
brigades during their intervention;

- Identification of problems they are facing during the intervention;

- Consideration, understandingand finding the possibilities for realization of all possible solutions for overcoming the current problems in this area.

Bearing in mind that the nature of work of the fire rescue brigades involves wellorganized and coordinated actions which enables the saving of human lives and assets, it is of great importance to research and find the best possible models and methods for successful performance of their tasks with the prerequisite that during such performance the participants are protected to the maximum, i.e. to provide them with safe working conditions. Through the variety of research and collection of attitudes and relevant opinions it is necessary to determine in which way is necessary to implement a good governance, to enable an appropriate decision making, uninterrupted and positive communication, successful resolution of various disputes and conflicts in the team that has very important task of rescuing the people and assets in the case of emergency situations. Identification of hazards, risk assessment (Архипова \& Кулъба, 1998) and establishment of risk management through the permanent education and training of the employees are the guidelines that will lead to healthier, safer and more productive working environment. Apart from necessary qualification and training, it is essential that members of fire rescue brigades are adequately equipped with personal and safety equipment of a high quality, and with means for extinguishing a fire, in order to reduce the possibilities of injury and even fatalities.

Along with the analysis of the current situation in relation to what is to be achieved with the tendency of gaining the insight between what "is"and what "will be", author's opinion is that the research in this areas and dealing with this issue shall contribute to a general social interest, and all for the purpose of raising the safety awareness, culture of crisis management, that is, upgrading, prevention or avoiding and minimization casualties and disruption of naturalresources and assets. The research goal is the identification and determination of requirements of the members of fire rescue brigades that operate in the conditions of a high risk, and all for the purpose of reduction of possibilities for injury during the intervention. The research should contribute to scientific "refreshment" of this issue and to establishment of more adequate projection of the model of safe and healthy working environment for the members of fire rescue brigade. Based on the afore mentioned goal, the theoretical and practical research tasks are formulated. Theoretical tasks of the research are:

- Defining and determination of basic research terms;

- Analysis of the nature of employment of the members of fire rescue brigades;

- The experience in the previous work with regard to the number and type of intervention;

- Analysis of the situation in the area of occupational safety and health of the members of fire rescue brigades with regard to the number of occupational injuries and occupational diseases. 


\section{Hypothetical framework of the research}

General hypothesis:

Fire rescue brigades that have more complex tasks tend to be more skilled, trained and technically equipped.

For the purpose of processing data, the following statistical methods were used: frequency, percentage, arithmetic mean and standard deviation.

\section{Results and discussion}

First, the structure of the sample regarding the employment status of the respondents and the examined sociodemographic variables was checked. Results are presented in the tables. The total number of respondents in the sample is 45 , and the percentages presented in the tables are calculated according to this number.

The results imply that all respondents are the members of professional fire brigades; all except one are the members of the local government fire departments. Just over three-quarters of respondents have secondary education, and only 10 respondents have higher levels of education. Two-thirds of respondents said to have technicaltechnological education background, while 15 respondents said to have social science and humanities education background or natural science and mathematical education background. In terms of age, the sample is diverse, with respondents in all three categories, although most respondents fall into the category from 31 to 45 of age. Out of total number slightly less than one-third of respondents are in managerial positions. Having this in mind, during a comparison by group, the comparison by type of fire brigade will not be carried out, because they all are the members of professional fire brigades, as well as for the formation that fire brigade belongs to, because all but one are the members of fire departments oflocal governments. In terms of education, taking into consideration the distribution of respondents by category, the comparisons are carried out between respondents with a high school education and those with the higher levels of education. In terms of the nature of education, the comparison is carried out between the respondents with technical-technological education and others.

Table 1 The statements of the respondents about the frequency of different types of emergency situations

\begin{tabular}{|l|c|c|c|c|}
\hline \multicolumn{1}{|c|}{ Type of emergency situation } & $\begin{array}{c}\text { Arithmetic } \\
\text { mean }\end{array}$ & $\begin{array}{c}\text { Standard } \\
\text { deviation }\end{array}$ & Minimum & Maximum \\
\hline $\begin{array}{l}\text { Natural character (earthquakes, floods, } \\
\text { landslides, forest fire) }\end{array}$ & 3.69 & 2.494 & 0 & 10 \\
\hline $\begin{array}{l}\text { Technical-technological character (traffic } \\
\text { accidents, fire on electric installations, } \\
\text { explosions, accidents in industry) }\end{array}$ & 3.98 & 2.547 & 0 & 10 \\
\hline $\begin{array}{l}\text { Ecological character (degradation of natural } \\
\text { environment) }\end{array}$ & 0.42 & 0.587 & 0 & 2 \\
\hline Terrorist acts, consequences of violence & 1.34 & 1.599 & 0 & 10 \\
\hline
\end{tabular}


When it comes to frequency of different types of emergency situations, it can be seen that respondents on average clearly emphasize the emergency situations of natural and technical-technological character. Emergency situations that are the consequence of terrorist acts and violence are rarely cited, while the rarest are emergency situations of ecological character.

When it comes to frequency of respondents' answer to a question on impact of special territorial-safety conditions in which they live on occupational and environmental safety, all 45 respondents stated that these conditions have such impact.

Distribution of respondents' answers to a question on importance of respondents' skills for application in the phases of prevention of emergency situation and intervention in emergency situation are given in the following table.

Table 2 Distribution of respondents' answers to a question on to what extent skills and abilities of respondents can apply in the phase of prevention-intervention of emergency situation

\begin{tabular}{|l|c|c|}
\hline \multicolumn{1}{|c|}{ In prevention phase? } & Number of respondents & Percentage \\
\hline Completely & 18 & 40 \\
\hline Partially In the intervention phase? & 27 & 60 \\
\hline \multicolumn{1}{|c|}{ Number of respondents } & Percentage \\
\hline Completely & 43 & 95.6 \\
\hline Partially & 2 & 4.4 \\
\hline
\end{tabular}

From the table it can be seen that almost all respondents believe that their skills and abilities are changeable in the intervention phase, but less than $50 \%$ believes that their skills are applicable in prevention phase. When it comes to the degree of familiarity of respondents with rights of employees that influence the occupational safety and health, these results are presented in Table 3 .

Table 3 Indicators of familiarity of respondents with rights that influence the occupational safety and health

\begin{tabular}{|c|c|c|c|}
\hline The employee's right & $\begin{array}{c}\text { I am familiar } \\
\text { with }\end{array}$ & $\begin{array}{l}\text { I am partially } \\
\text { familiar with }\end{array}$ & $\begin{array}{c}\text { I am not } \\
\text { familiar with }\end{array}$ \\
\hline $\begin{array}{l}\text { A) the employee prior to engagement is entitled to be } \\
\text { introduced with the measures of safety and health at the } \\
\text { place where he is assigned }\end{array}$ & $\begin{array}{c}9 \\
(20.0 \%)\end{array}$ & $12(26.7 \%)$ & $\begin{array}{c}24 \\
(53.3 \%)\end{array}$ \\
\hline $\begin{array}{l}\text { B) the employee has right to control his own health } \\
\text { (preliminary of periodical medical examination of the } \\
\text { employees) according to the risks of the workplace }\end{array}$ & $\begin{array}{c}9 \\
(20.0 \%)\end{array}$ & $\begin{array}{c}17 \\
(37.8 \%)\end{array}$ & $\begin{array}{c}19 \\
(42.2 \%)\end{array}$ \\
\hline $\begin{array}{l}\text { C) The employee is entitled to reimbursement for salary } \\
\text { payment in the amount of average monthly earnings } \\
\text { during the period oftemporary inability to work caused } \\
\text { by injury at work }\end{array}$ & $\begin{array}{c}16 \\
(35.6 \%)\end{array}$ & $\begin{array}{c}10 \\
(22.2 \%)\end{array}$ & $\begin{array}{c}19 \\
(42.2 \%)\end{array}$ \\
\hline $\begin{array}{l}\text { D) the employee is entitled to nutrition, accommodation } \\
\text { and payment reimbursement during the professional } \\
\text { training and education }\end{array}$ & $\begin{array}{c}20 \\
(44.4 \%)\end{array}$ & $\begin{array}{c}6 \\
(13.3 \%)\end{array}$ & $\begin{array}{c}19 \\
(42.2 \%)\end{array}$ \\
\hline $\begin{array}{l}\text { Right } \\
\text { (Range of answers 1-completely familiar with , 3-not } \\
\text { familiar with), less AS indicates a higher degree of } \\
\text { familiarity }\end{array}$ & $\begin{array}{l}\text { Arithmetic } \\
\text { mean }\end{array}$ & $\begin{array}{l}\text { Standard } \\
\text { deviation }\end{array}$ & I \\
\hline
\end{tabular}




\begin{tabular}{|l|l|l|l|}
\hline $\begin{array}{l}\text { A) the employee prior to engagement is entitled to be } \\
\text { introduced with the measures of safety and health at the } \\
\text { place where he is assigned }\end{array}$ & 2.33 & 0.798 & \\
\hline $\begin{array}{l}\text { B) the employee has right to control his own health } \\
\text { (preliminary of periodical medical examination of the } \\
\text { employees) according to the risks of the workplace }\end{array}$ & 2.22 & 0.765 & 0.889 \\
\hline $\begin{array}{l}\text { C) the employee is entitled to reimbursement for salary } \\
\text { payment in the amount of average monthly earnings } \\
\text { during the period of temporary inability to work caused } \\
\text { by injury at work }\end{array}$ & 2.07 & 0.941 & \\
\hline $\begin{array}{l}\text { D) the employee is entitled to nutrition, accommodation } \\
\text { and payment reimbursement during the professional } \\
\text { training and education }\end{array}$ & 1.98 & \\
\hline $\begin{array}{l}\text { Note: in the table are presented frequencies (number of respondents) in the upper field, while percentage is } \\
\text { presented in the lower field }\end{array}$ & & \\
\hline
\end{tabular}

From the results is evident that about $50 \%$ of respondents stated that were not familiar with given rights, while others stated that were partially or completely familiar. In average, the respondents are the most familiar with the rights to nutrition, accommodation and salary compensation during the professional training and education, even though the variability of respondents' answers is the highest. The answers of the respondents indicate that they are less familiar with a right to become familiar prior to engagement with measures of safety and health in a workplace they are assigned to.

When it comes to injuries at work, the distribution of respondents' answers are given in the following table.

Table 4 The number of respondents who stated that during the last year has suffered injury at work and factors to which contribute the occurrence of the injury

\begin{tabular}{|l|c|c|}
\hline \multicolumn{1}{|c|}{ Have you suffered an injury at work during the last year? } & $\begin{array}{c}\text { Number of } \\
\text { respondents }\end{array}$ & Percentage \\
\hline Yes & 9 & 20.0 \\
\hline No & 36 & 80.0 \\
\hline \multicolumn{1}{|c|}{ What hazard led to injuries? } & $\begin{array}{c}\text { Number of } \\
\text { respondents }\end{array}$ & Percentage \\
\hline Failures in management & 1 & 2.2 \\
\hline Poor communication in a team & 0 & 0 \\
\hline High risk of slipping and tripping & 2 & 4.4 \\
\hline Exposure to high temperature & 5 & 11.1 \\
\hline Exposure to & 4 & 8.9 \\
\hline Demolition of parts of the building affected by fire & 2 & 4.4 \\
\hline Work at height (hydraulic ladders) & 0 & 0 \\
\hline Indirect contact ofelectrical installations and equipment under voltage & 0 & 0 \\
\hline Danger caused by other endangered persons & 0 & 0 \\
\hline Inadequate mobile equipment for extinguishing of fire & 0 & 0 \\
\hline Obsolete personal equipment & 0 & 0 \\
\hline Other hazards (respondents cited bomb explosion) & 2 & 4.4 \\
\hline $\begin{array}{l}\text { Note: The calculation of percentage regarding the answer to type of hazard that led to injury relates to total } \\
\text { number of respondents in a sample. }\end{array}$ & & \\
\hline
\end{tabular}


From the table it can be seen that $20 \%$ of respondents said that they have suffered an injury at work in the past year. When it comes to the type of danger that led to the injury, respondents most frequently cited exposure to high temperatures and smoke, while two respondents cited as a threat that led to injure due to the demolition of parts of the building affected with flame, slipping and stumbling and bomb explosion.

Next are the observed answers to questions on familiarity with the issues of occupational safety and health, and readiness for acquisition of new and upgrading of existing knowledge, skills and abilities in this area. Distribution of respondents' answers to these questions is given in the table below.

Table 5 Distribution of respondents' answers on familiarity with the issues of occupational safety and health

\begin{tabular}{|l|c|c|}
\hline \multicolumn{1}{|c|}{$\begin{array}{c}\text { Are you familiar enough with the issues of occupational safety and } \\
\text { health? }\end{array}$} & $\begin{array}{c}\text { Number of } \\
\text { respondents }\end{array}$ & Percentage \\
\hline Yes & 12 & 26.7 \\
\hline No & 33 & 73.3 \\
\hline What are the main reasons for insufficient familiarity with these issues? & $\begin{array}{c}\text { Number of } \\
\text { respondents }\end{array}$ & Percentage \\
\hline No answer & 6 & 13.3 \\
\hline $\begin{array}{l}\text { Lack of knowledge and failure to comply with regulations in the area of } \\
\text { occupational safety and health }\end{array}$ & 10 & 22.2 \\
\hline $\begin{array}{l}\text { Irresponsible and inadequate behaviour of the employer in implementing } \\
\text { the safety and health at work }\end{array}$ & 9 & 20.0 \\
\hline $\begin{array}{l}\text { Negligence and deprivation of rights of employees in the domain of } \\
\text { occupational safety and health }\end{array}$ & 9 & 20.0 \\
\hline Lack of information and training on occupational safety and health & 11 & 24.4 \\
\hline
\end{tabular}

From the results it is evident that almost three quarters of respondents believe that were not sufficiently familiar with the issues of occupational safety and health. Regarding the reasons for the lack of awareness, therespondents with almost the same frequency stated each of the four given answers.

Table 6 Distribution of the respondents' answers to questions on readiness for acquisition of new knowledge, skills and abilities from the area of occupational safety and health, and about preferred methods and places for acquisition of this knowledge and previous experiences with training for response in emergency situations

\begin{tabular}{|l|c|c|}
\hline $\begin{array}{c}\text { Would you like to acquire new or expand the existing knowledge, skills } \\
\text { and abilities concerning the occupational safety and health? }\end{array}$ & $\begin{array}{c}\text { Number of } \\
\text { respondents }\end{array}$ & Percentage \\
\hline Yes & 44 & 97.8 \\
\hline No & 1 & 2.2 \\
\hline $\begin{array}{l}\text { In what way would you like to acquire certain knowledge for the } \\
\text { occupational and environmental protection including the occupational } \\
\text { safety and health? }\end{array}$ & $\begin{array}{c}\text { Number of } \\
\text { respondents }\end{array}$ & Percentage \\
\hline Lectures in traditional face-to-face classroom & 11 & 24.4 \\
\hline Group discussions & 2 & 4.4 \\
\hline Self-education & 1 & 2.2 \\
\hline Public lectures, panel discussions & 4 & 8.9 \\
\hline Seminars, courses and workshops & 28 & 62.2 \\
\hline
\end{tabular}




\begin{tabular}{|c|c|c|}
\hline Through the media & 0 & 0 \\
\hline $\begin{array}{l}\text { Where would you like to gain knowledge and skills required for work } \\
\text { performance? }\end{array}$ & $\begin{array}{l}\text { Number of } \\
\text { respondents }\end{array}$ & Percentage \\
\hline In the work organization & 19 & 42.2 \\
\hline In the academic institution & 1 & 2.2 \\
\hline At home & 0 & 0 \\
\hline In a different education centres & 25 & 55.6 \\
\hline $\begin{array}{l}\text { Have you ever attended training, courses and seminars relating to } \\
\text { practicing procedures and verification of action plan in emergency } \\
\text { situations? }\end{array}$ & $\begin{array}{l}\text { Number of } \\
\text { respondents }\end{array}$ & Percentage \\
\hline Yes & 21 & 46.7 \\
\hline Occasionally & 11 & 24.4 \\
\hline No & 13 & 28.9 \\
\hline
\end{tabular}

The data show that almost all respondents expressed their readiness to acquire new or expand the existing knowledge, skills and abilities in the area of occupational and environmental safety. As the main ways for acquisition of such knowledge they cited seminars, courses and workshops, as well as the traditional lectures; and asplaces where they would like to acquire these skills they cited different education centres and work organization. Approximately $30 \%$ of respondents stated that they did not attend any trainings, courses and seminars relating to practicing of procedure and verification of action plan in emergency situations. When asked about the type of the training they attended so far, out of 45 respondents 24 gave an answer to a question (of any type). From those 24 respondents, 15 answered with Elementary (elementary course), while 5 more respondents also stated Elementary but with additional specification - first aid, traffic accidents, elementary course of command; 3 respondents stated training for rescuing from the ruins and traffic accidents, while one respondent at type of the training stated the training at the workplace.

Distribution of the respondents' answers to a question regarding the cooperation with authorities and other services that have an important role in the occupational and environmental protection is given in the following table.

Table 7 Distribution of the respondents' answers to a question regarding the cooperation with authorities and other services that have an important role in the occupational and environmental protection

\begin{tabular}{|l|c|c|}
\hline $\begin{array}{c}\text { What is the cooperation with the competent authorities and other } \\
\text { services that have a significant role in the protection of working and } \\
\text { living environment? }\end{array}$ & $\begin{array}{c}\text { Number of } \\
\text { respondents }\end{array}$ & Percentage \\
\hline Good & 17 & 37.8 \\
\hline Mostly good & 21 & 46.7 \\
\hline Bad & 7 & 15.6 \\
\hline
\end{tabular}

The table shows that $85 \%$ of the respondents, that is, a very big majority of respondents assessed cooperation with the competent authorities and other services in occupational and environmental protection as good or mostly good, while only 7 respondents assessed it as a bad. 
The respondents were then asked to assess the degree of readiness they encounter in their organizations to support further education and upgrading for better safety of working and living environment. They were also asked to cite the factors which are an obstacle to such education, subjects that should be included in education programs in this area and the ways that could contribute to achievement of better preparedness for adequate and efficient reaction in the emergency situations. Distributions of the respondents' answers to these questions are given in Table 8 and 9.

Table 8 Distributions of the respondents' answers to question on the degree of readiness they encounter in their organizations to support further education and upgrading for better occupational and environmental safetyand on factors which are obstacles to such education

\begin{tabular}{|l|c|c|}
\hline \multicolumn{1}{|c|}{$\begin{array}{c}\text { Does your organization expresses readiness to support your further } \\
\text { education and upgrading for better safety of your working and living } \\
\text { environment? }\end{array}$} & $\begin{array}{c}\text { Number of } \\
\text { respondents }\end{array}$ & Percentage \\
\hline Yes & 29 & 64.4 \\
\hline No & 15 & 33.3 \\
\hline Did not answer & 1 & 2.2 \\
\hline $\begin{array}{l}\text { Which of the following reasons represent an obstacle in your further } \\
\text { education and upgrading? }\end{array}$ & $\begin{array}{c}\text { Number of } \\
\text { respondents }\end{array}$ & Percentage \\
\hline Poor financial situation & 17 & 37.8 \\
\hline Unsafe area where I live & 7 & 15.6 \\
\hline Education centres are far away & 6 & 13.3 \\
\hline The lack of prompt information on possibilities for desired learning & 4 & 2.9 \\
\hline $\begin{array}{l}\text { The unwillingness of management to give you the opportunity to } \\
\text { continue your education and upgrading }\end{array}$ & 1 & 2.4 \\
\hline Other reasons & 1 & \\
\hline $\begin{array}{l}\text { The percentages in answer to a question about the reasons for obstacles are in relation to the overall sample, since } \\
\text { in this question respondents had the opportunity to circlemultiple answers. }\end{array}$ & \\
\hline
\end{tabular}

The table shows that about $65 \%$ of the respondents stated that in their organizations support them in further education and upgrading, while just over one-third do not have such support. When it comes to factors that present obstacles for further education and upgrading, the majority of respondents as a reason cited a poor financial situation (just over one-third). Other two most frequent reasons are the unsafe area where respondents live and remoteness of education centres. Four respondents as a reason cited the lack of prompt information regarding on possibilities for upgrading as a reason; two respondents circled the remained two options, respectively.

Table 9 Distribution of the respondents' answers to questions about the subjects that should be included in education program in this area and about the ways that could contribute to better preparedness for adequate and efficient reaction in emergency situations

\begin{tabular}{|c|c|c|}
\hline $\begin{array}{l}\text { How the education for occupational and environmental protection can } \\
\text { help you? }\end{array}$ & $\begin{array}{l}\text { Number of } \\
\text { respondents }\end{array}$ & Percentage \\
\hline $\begin{array}{l}\text { In identification, assessment and management of risks in working } \\
\text { and living environment that can lead to emergency situations (risk } \\
\text { management) }\end{array}$ & 21 & 46.7 \\
\hline
\end{tabular}




\begin{tabular}{|c|c|c|}
\hline $\begin{array}{l}\text { In acquisition of knowledge and skills for management in emergency } \\
\text { situations }\end{array}$ & 16 & 35.6 \\
\hline $\begin{array}{l}\text { In acquisition of knowledge and skills for helping jeopardized population } \\
\text { (medical assistance during the evacuation andtaking care) }\end{array}$ & 21 & 46.7 \\
\hline $\begin{array}{l}\text { Introduction to all subject of response to emergency situations and } \\
\text { possibilities for joint work and cooperation }\end{array}$ & 18 & 40.0 \\
\hline $\begin{array}{l}\text { In acquisition of knowledge and skills to adequately inform and } \\
\text { communicate with the public in the case of emergency situation }\end{array}$ & 5 & 11.1 \\
\hline $\begin{array}{l}\text { In exploring the possibilities and ways of recovering from emergency } \\
\text { situations }\end{array}$ & 10 & 22.2 \\
\hline Something else & 0 & 0 \\
\hline $\begin{array}{l}\text { In your opinion, what is the way for achievement of better preparedness } \\
\text { for adequate and efficient response in the conditions of emergency } \\
\text { situations? }\end{array}$ & $\begin{array}{l}\text { Number of } \\
\text { respondents }\end{array}$ & Percentage \\
\hline By implementing the subjects from this area in school programs & 4 & 8.9 \\
\hline By creating a special education programs from this area & 5 & 11.1 \\
\hline Education of professional staff to deal with this issue & 17 & 37.8 \\
\hline Education of all parties who are responsible for this issue & 14 & 31.1 \\
\hline Permanent education and training of the competent services and bodies & 3 & 6.7 \\
\hline $\begin{array}{l}\text { Development of and access to appropriate literature on the subject } \\
\text { (manuals, brochures, etc.). }\end{array}$ & 5 & 11.1 \\
\hline $\begin{array}{l}\text { For ensuring safe working and living environment, according to your } \\
\text { opinion, is necessary }\end{array}$ & $\begin{array}{l}\text { Number of } \\
\text { respondents }\end{array}$ & Percentage \\
\hline To organize workshops with members of different services & 10 & 22.2 \\
\hline To publish manuals and technical literature in this area & 2 & 4.4 \\
\hline To organize professional visits to departments in other countries & 2 & 4.4 \\
\hline To organize learning from crises - work with the population & 6 & 13.3 \\
\hline To engage an expert to conduct continuing education services in this area & 3 & 6.7 \\
\hline To consistently obey and enforce regulations in this field & 6 & 13.3 \\
\hline Better equipment and means of personal protection & 13 & 28.9 \\
\hline Greater financial, material and technical support & 14 & 31.1 \\
\hline
\end{tabular}

When it comes to areas in which respondents want assistance from the education in the field of occupational and environmental protection in emergency situations, about $50 \%$ of respondents stated that they need further education for the purpose of identification, assessment and management of the risks that can lead to emergency situations. The same number of respondents stated that education would be helpful in acquiring knowledge and abilities to help jeopardized population. Fewer stated that it would be helpful to get familiar with all subjects of response to emergency situations and possibilities of joint work and cooperation, as well as to acquire knowledge and abilities for leadership and management in emergency situations through the education. Knowledge in the field of communication with the public is less frequently stated as knowledge that would help respondents.

When it comes to achieving the better preparedness for response in emergency situations, the majority stated that preparedness could be upgraded by educating the professional staff for this issue, as well as by educating all subjects responsible. One-third of respondents stated both as an important factors of better preparedness for adequate and efficient response in emergency situations. Creation of special education programs and access 
to appropriate literature were stated by 5 respondents, while the number of respondents stating some of other reasons is even lesser.

When it comes to means and activities required for ensuring the safe working and living environment, according to respondents' opinion, the most important are financial and material-technical support, better equipment and means for personal protection. Slightly fewer respondents believed that it would be important to organize workshops with the members of different departments. Six respondents stated that learning from crisis situationsworking with population should be organized and that for this purpose it is important to obey and implement regulations regarding this area. The remaining three offered options were selected only by a couple of respondents.

\section{Conclusion}

Successful resolution of issues and problems regarding the protection of working and living condition requires a strong institutional basis, which could be accomplished by strengthening of capacities, good governance, facilitated flow of information and efficient coordination. It is necessary to establish stronger correlations between formal, informal and other forms of learning and education in order to introduce philosophy and practice of lifelong learning, that is, ability to update and upgrade knowledge and abilities throughout life.

Based on the results of the research, the following conclusions can be made:

Answers, attitudes and opinions of the respondents indicate that most of them shows highly express willingness and preparedness to further education and training, which is actually encouraging because only well trained and skilled firemen-rescuers can respond to all the challenges and dangers while protecting themselves, citizens, material goods and the environment in which they live.

It is important to note that the financial and economic situation is the main cause of outdated technology and equipment as well as for insufficient equipment of adequate personal protective equipment and resources.

Results indicate that there is a high awareness of firefighters-rescuers regarding their personal responsibility for the provision of adequate protection to the population in situations where their lives are jeopardized by some threatening danger.

Through most of the answers, attitudes and opinions, it can be concluded that respondents by their answers have confirmed research hypothesis and thus contributed to further efforts to view this issue as an issue of general social importance and interest.

Regarding the results of the research, after analysis of the respondent's opinions and answers, it seems advisable to point out to some objective and necessary measures and research activities that could be achieved in the following directions in regards to the futher advancement of national management of emergency situations in general:

- Content and topics in the area of protection of working and living environment, especially content in the area of occupational safety and health should be introduces in the national curricula of all institutions of education;

- To overcome or prevent barriers of population participation in activities of education concerning protection of working and living environment;

- To encourage the activities of the family, school, media and various social organization in developing educational needs for protection of working and 
living environment, especially in the areas that are exposed to risks of occurrence of emergency situations;

- $\quad$ To provide a system of permanent education and learning in the field of protection of working and living environment both at the national and local level;

- To achieve a functional correlation of scientific-research organizations with the members of fire rescue brigades;

- To develop awareness and culture of the citizens' safety in the area of protection and rescuing and to reduce disaster risks;

- To establish and promote more efficient coordination and operative cooperation between the members of fire rescue brigade and all subjects responsible for the safety of working and living environment;

- To improve regional and international coordination and cooperation of monitoring the condition by information exchange and joint trainings of fire rescue brigades on safety issues of working and living environment.

This research does make important and significant contribution to improvement of domestic national system of emergency situations management in ensuring safe working and living environment in line with the current needs of working and living environment's safety. Further studies based on this research's model should be conducted with a wider range of respondents or even from different countries in order to analize and compare their attitudes and opinions and improve their safety in general.

\section{References}

Архипова, Н.И., Кулъба, В.В. (1998). Управленије Чрезвьичаи́ньих ситуациях. Москва, РУ: Российский государственный гуманитарный университет.

Boin, A. (2009). The New World of Crises and Crisis Management: Implications for Policy making and Research. Review of Policy Research, 26(4), 367-377.

Boin, A., Ekengren, M. \& Rhinard, M. (2013). The European Union as Crisis Manager Patterns and Prospects. Cambridge, UK: Cambridge University Press.

Beaton, R., Corneil, W., Johnson, C., Murphy, S. \& Pike, K. (1999). Coping responses and posttraumatic stress symptomatology in urban fire service personnel. Journal of Traumatic Stress, 12(2), 293-308.

Chen, H., Pittman, W.C., Hatanaka, L.C., Harding, B.Z., Boussouf, A, Moore, D.A., Milke, J.A. \& Mannan, M.S. (2015). Integration of process safety engineering and fire protection engineering for better safety performance. Journal of Loss Prevention in the Process Industries, 37, 74-81.

Ford, J.K. \& Schmidt, A.M. (2000). Emergency response training: strategies for enhancing real-world performance. Journal of Hazardous Materials, 75(2-3), 195-215.

Helsloot, I. (2008). Editorial: Coordination is a prerequisite for good collaboration, Isn't it? Journal of Contingencies and Crisis Management, 16(4), 173-176.

Hollis, S. (2014). Arational response to natural disasters: Explaining the global rise of regional disaster risk management, Phd dissertation, Berlin, DE: Hertie School of Governance. 
Kazmierczak, L. (2011). Det Som ar Hart or lettere Att Knacka, in N.O. Nilsson, (Ed.), Samverkan - för säkerhets skull!, (pp. 207-217). Stockholm: Myndigheten för samhällsskydd och beredskap (MSB).

Keković, Z. \& Kešetović, Ž. (2006). Crisis management: Prevention of crisis. Belgrade, SR: The Faculty of Security Studies.

Mastrjukov, B.S. (2005). Safety in emergency situations. Moskva, RU: MGU Lomonosov.

Moran, C. \& Britton, N.R. (1994). Emergency work experience and reactions to traumatic incidents. Journal of Traumatic Stress, 7(4), 575-585.

Tercovich, G. (2014). Towards a Real Comprehensive Approach. Journal of Contingencies and Crisis Management, 22(3), 150-157.

The Law on Emergency Situations, "Official Gazette of the Republic of Serbia”, No. $111 / 2009,92 / 2011,93 / 2012$.

Qinqin, C., Jia, Q., Yuan, Z. \& Huang, L. (2014). Environmental risk source management system for the petrochemical industry. Process Safety and Environmental Protection, 92(3), 251-260.

Živković, S. (2011).Organization of fire protection. Niš, SR: Faculty of occupational safety in Niš. 